\author{
A New Twist on the "Un-African" Script: \\ Representing Gay and Lesbian African Weddings in Democratic South Africa
}

\author{
Michael W. Yarbrough \\ John Jay College of Criminal Justice (CUNY)
}

This article has been published in revised form in Africa Today. The final version is available at https://www.doi.org/10.2979/africatoday.67.1.04.

\begin{abstract}
This essay examines the media coverage surrounding two African-style weddings of lesbian and gay couples in South Africa, as a lens onto the evolving cultural politics of black queerness in that country. Two decades after South Africa launched a world-leading legal framework for LGBTI protections, I argue that these media representations depict the growing inclusion of black LGBTIQ people as a process of "bridging" the supposed "gap" between homosexuality and African culture. This new "bridging the gap" script seemingly rejects the older, dominant script portraying homosexuality as intrinsically "un-African." But I argue that it instead reproduces the "un-African" script in a new, liberal guise, offering inclusion to black LGBTIQ South Africans on limited terms that continue to obscure their embeddedness within African histories and communities.
\end{abstract}

ACKNOWLEDGEMENTS: Earlier versions of this article were presented at the Northeast Workshop on Southern Africa, and at the American Sociological Association. I thank those audiences as well as Rafael de la Dehesa, Casey Golomski, Ke Li, Nicholas Smith, T.J. Tallie, 
Mengia Tschalär, and two anonymous reviewers and the editors at Africa Today for suggestions and feedback that improved this essay.

\section{The First}

Everyone was sure it was the first. The first what was harder to pin down.

It began, in January 2013, as the first legal gay wedding in the area. That's how a smalltown paper in the province of KwaZulu-Natal $(\mathrm{KZN})$ put it in a front-page feature about the African-style wedding that Thoba Sithole and Tshepo Cameron Modisane were planning to hold there in KwaDukuza, Thoba's ${ }^{1}$ hometown. Mamba Online, a national LGBTQ ${ }^{2}$ news and lifestyle website, repeated this description in an interview they ran with the couple on Valentine's Day (Igual 2013). But they also hinted at a bigger story. Could the couple become role models for gay people of color across the country-or even the continent?

Reporting on the preparations in early April, national 24-hour cable news network eNCA (2013a) told viewers that the couple were "breaking brave new ground" with a "small-town KZN wedding of a very different kind." They interviewed a "scholar of African culture" who dismissed the wedding, saying that "we have never heard of such a thing in our culture, our tradition." Meanwhile, a local neighbor was excited. "This always happens far from us, and now we get to see it ourselves. We are curious to see how it will all happen."

The next day, eNCA (2013b) uploaded a second segment from the wedding itself onto their Youtube channel with the title, "Traditional African gay wedding a first." From there the news went viral. In the UK, LGBTQ newspaper Pink News described the ceremony as "uniting Zulu and Tswana traditions" in "the area's "first legal gay wedding"” (Pinfold 2013). U.S. LGBTQ blog Towleroad (2013) called it "the area's first traditional African gay wedding," while 
the Huffington Post (2013) also called it the "first traditional gay wedding" not just in the area but in all of Africa, albeit with a question mark: "Africa's first traditional gay wedding?"

From here this frame shed its question mark and achieved global liftoff. On a Brazilian news website, it was the "first gay wedding in a traditional African ceremony" (Sul 21 2013). In UK newspaper the Mail (2013), the ceremony was "Africa's first traditional gay wedding," as it also was on African-American websites Black Enterprise (Gaynor 2013) and NewsOne (2013). German newspaper Der Spiegel called it "the first official, traditional gay wedding” (Dürr 2013) and most African outlets who covered the story also highlighted the "official" or "legal" nature of the "first" (see, e.g., FAB Blog 2013; Naijalog 2013). Meanwhile, back home in South Africa, the country's largest newspaper conglomerate was still using a more localized description — “the town's first gay marriage"- but under the sensationalist headlines, "Pair tie bold knot" in one outlet (Nofemele 2013a), and "YES I DO...! The stylish gay Zulu wedding” in another (Nofemele 2013b).

By now the town was no longer a town, but a symbol; the wedding no longer a wedding, but a sensation and a scandal. While South African outlets largely avoided foreign media's most sweeping "first" descriptions, the binary underlying those foreign descriptions_- "African culture" on one side, homosexuality on the other, and a defining gap between - was the takenfor-granted basis of local coverage, too. KwaDukuza, located on the site of a former royal settlement established by King Shaka himself, stood in for African culture (see, e.g., de Waal 2013). Cameron and Thoba, a young professional couple living together in a Johannesburg apartment, for homosexuality. "And then," as eNCA (2013b) reporter Nontobeko Sibisi put it, "the moment guests had been waiting for": the kiss. The image of Thoba in Zulu springbok skins 
taking Cameron's head in Tswana fur cap and pulling him in for the kiss became the video's thumbnail image on Youtube. Click here, it beckoned, and watch a historic binary explode.

One decade after the legal enactment of same-sex marriage and two after the formal end of apartheid, the cultural politics of queerness in South Africa are more complex than ever. For many years, the standard story of South African queer life has emphasized the chasm between the country's world-leading framework of laws claiming to protect LGBTIQ people, and its world-infamous epidemic of violence actually harming them (for critiques of this standard story, see Matebeni 2014; Matebeni and Msibi 2015). Many observers, especially outside of Africa, have tended to blame the struggles of black ${ }^{3}$ LGBTIQ South Africans on "African homophobia," a hostility to homosexuality supposedly rooted in a supposedly monolithic "African culture" (Awondo, Geschiere, and Reid 2012; Coly 2013; Judge 2017). And indeed, many black Africans themselves, in South Africa and across the continent, have claimed that homosexuality is "unAfrican," unknown in African communities historically and impossible there today without undue Western influence. These two tropes, "African homophobia" from one side and "unAfrican homosexuality" from the other, have scripted much the same story from different angles, effectively colluding to produce a seeming transracial, transnational, and trans-political consensus that an unbridgeable gap separates "African culture" and "homosexuality" (Coly 2013).

Meanwhile, South Africa has also enacted perhaps the strongest protections for LGB people anywhere in the world, along with similar protections around gender and trans equality. Even with the well-known gap separating the country's legal promises from its lived realities, the gender and sexuality protections that followed the democratic constitutions have had a real 
impact on the ways many South Africans, especially women and LGBTIQ-identified people, understand their everyday rights and responsibilities (see, e.g., Judge 2017; Mnisi Weeks 2017; Yarbrough 2018a). The constitution created legally protected space within which organized sexuality activism has blossomed (Currier 2012), and perhaps even more importantly, it provided a legitimizing narrative that tied freedom of sexual orientation to the broader democratic freedoms secured in the anti-apartheid struggle (Hoad 2007). This has in turn provided many everyday South Africans, especially black South Africans, more space to imagine and represent themselves as LGBTI and/or Q.

And so, as South Africa's constitutional democracy has matured, the "un-African" script has become harder and harder to sustain. This is especially true in the mainstream Englishlanguage news media, which generally speaks to multiracial, urban audiences from a broadly liberal position that emphasizes formal equality and tolerance for cultural diversity. As this diversity has been firmly defined in law to include sexual orientation, the mainstream media has generally followed suit. At the same time, the mainstream media has also generally accepted the received wisdom that "African culture" is intrinsically patriarchal and heterosexual. And so the problem emerges: The media sees black LGBTIQ South Africans as legitimate, but struggles to fit their growing visibility into a script of exclusively heterosexual African culture.

To explore this tension, in this essay I examine the media coverage of two South African wedding processes, one gay and one lesbian, that included elements understood as traditionally African. These two weddings_-Thoba Sithole and Cameron Modisane's wedding in 2013, introduced above, and the lobola (roughly: bridewealth) process of lesbian couple Sape Maodi and Vaivi Swartz in 2015, introduced below-became stories because the media perceived them as threshold events in the struggle over homosexuality in Africa. I collected all English- 
language $\mathrm{e}^{4}$ print and TV coverage of the weddings that I could locate, and read and summarized each story with particular attention to how it framed the gay or lesbian wedding process and any conflict around it. I then compiled all quotes from each of the couples themselves in their respective coverage, reading the body of quotes together for insight into how the couples framed their own experiences when speaking to the media.

In each case, the couple told a complex story that emphasized their embeddedness in African communities, while the media arranged and framed these quotes into a binary script that presented the couples and their families as "bridging the gap," as one story put it, between homosexuality and African culture. Clothing the "un-African" script in liberal garb, this "bridging the gap" script begins from the existing premise that homosexuality has been historically un-African, but then continues on to suggest that LGBTIQ black South Africans can teach their families and communities to unlearn their ancient prejudices. The "bridging the gap" script tracks both dominant scripts in global LGBT rights politics that frame education as the path to overcoming homo- and transphobia, and longstanding colonial scripts that frame Africans as sexually premodern (Lewis 2011; Patil 2018; Tallie 2013; Tamale 2011). While the "bridging the gap" script offers inclusion to black LGBTIQ South Africans, it does so on limited terms that continue to obscure their embeddedness within African histories and communities. Framing the black family as the site of LGBTIQ vulnerability, this script misrepresents the complex stories black LGBTIQ people themselves tell, and it excises queerness from ongoing African historiesmost especially broader histories of gender struggle.

I use the metaphor of a "script" in this essay to describe the repeated use of a single plot to narrate every event the script is thought to cover. The "un-African" script, for example, narrates every instance of African queerness as a tragedy of foreign influence, a wayward son or 
daughter led astray by fashion or money (Currier 2012; Reid 2013; Tamale 2013). The "bridging the gap" script I examine here, meanwhile, narrates these new African lesbian and gay weddings as progress stories of historic breakthrough between the gays and the Africans. Both of these scripts cast the stories' participants into antagonistic roles squared off in binary conflict. And by doing so, both scripts reproduce broader discourses about the linked architecture of racial, gender, and sexual difference.

In the next section, I begin by examining the presumed "newness" of these weddings, focusing on Thoba and Cameron's nuptials. Then I analyze how this assumption of "newness" filtered the complex narratives LGBTIQ people themselves told through the "bridging the gap" script. Here I focus on Vaivi and Sape's lobola, where the women described multilayered reactions from family members, only to have reporters flatten their story into a simple script of "bridging the gap." The media coverage of these weddings indexed the growing acceptance many black LGBTIQ people experience in their communities. But it did so while helping to reproduce, in new form, the "un-African" script they were struggling against in the first place.

\section{Everything Old is New Again: Cameron Modisane \& Thoba Sithole}

At the core of this reproduction was the emphasis on the weddings' supposed "newness," an emphasis especially central to the confetti of "firsts" showered on Cameron and Thoba's wedding. This wedding's newness was its story, provoking the clicks and shares that carried the couple's kiss from KwaDukuza to the globe. Cameron himself shared his excitement about "making history" (eNCA 2013a) and his desire "to show the people of this country that, yes-it is possible to have a traditional African gay wedding" (de Waal 2013). But the media and the couple described that newness in different ways, situating it within two different narratives about 
queerness in Africa. For the media, what was new was the fact of two men in an African marriage. Under the sway of the "un-African" script, the media assumed that same-sex relationships had no historical basis among Africans. For the couple, by contrast, the newness was less about their same-sex relationship than about the public nature of the wedding: less about the doing than the showing (see also Msibi 2011). Through their wedding, Cameron and Thoba hoped to show that relationships like theirs already existed in African communities, and that African communities would accept them.

\section{The Couple's Visibility Strategy}

"The whole notion [of the wedding]," Cameron said, "is to quash the idea that being gay is un-African" (eNCA 2013b). "Gays have been living amongst us since time immemorial," he continued. "Even in the rural areas and also in the townships, we've always had gay people living as part of the community." But what had allowed the "un-African" script to deny the undeniable, Thoba suggested, was the secrecy surrounding same-sex relations. As he told Mamba before the wedding, "Hiding who we are is what makes people judge us even more and makes them not accept us for who we are. If we can just live life openly then in time people will get used to the idea that gay and lesbian people are part of society and we are here to stay" (Igual 2013). In a follow-up interview a year later, Thoba was careful to emphasize that they had married for love rather than publicity (DeBarros 2014). But while publicity was not the reason for the marriage, it was a goal for the ceremony itself. With their wedding, the couple were pursuing a kind of visibility politics that is a hallmark of mainstream LGBT rights activism around the globe (Currier 2012). 
And for the kind of visibility they sought, a ceremony others would recognize as specifically African was needed. Black gay and lesbian couples had long been marrying in white weddings, where "white" refers to the color of the bridal dress and, even more, the racialized origins of the ritual. Cameron and Thoba themselves had married in the government Department of Home Affairs one month prior to the KwaDukuza ceremony. ${ }^{5}$ But these weddings did not challenge the "un-African" script the way Thoba and Cameron hoped to do.

Cameron consistently mentioned three key elements that marked the KwaDukuza wedding as "traditional." First, the families slaughtered a bull to introduce each new spouse to the others' deceased ancestors and to request that the ancestors bless the wedding. Second, the proceedings included an umabo exchange of gifts between the two families, "which is also," Cameron said, "very traditional" (eNCA 2013a). And finally, perhaps most important to triggering the media frenzy, they wore what Cameron called "our traditional regalia." The image of the couple in their skins and furs-looking in each other's eyes, saying their vows, leaning in for the kiss - became the moment guests around the world discovered they had been waiting for.

The message the couple intended their African wedding to send was encapsulated in one of Cameron's favorite talking points, already mentioned: "Gays have been living amongst us since time immemorial" (eNCA 2013a). He referred to "[s]tudies by historians and anthropologists [that] have found same-sex relationships to have been in existence in precolonial Africa," elaborating in a blog post that "[p]re-colonial Africa contained a range of approaches to sexual behavior, including many which permitted same-sex relationships to exist without violating social norms. What colonialism introduced was a binary model of sexuality, and systems of jurisprudence that identified and regulated sexual behavior to conform to the norms of the coloniser" (Modisane 2013). Cameron's claims to history were not limited to the 
pre-colonial. "We grew up in a township," he said, referring to the segregated black urban communities built under colonial and apartheid rule, "and homosexuals have always been around us even though they were ridiculed by members of the community." As he put it in another of his repeated talking points, "Being gay is as African as being black" (eNCA 2013a), by which he seemed to mean that the existence of gay Africans was an immovable fact.

His point was not only that gay Africans exist. It was also that African communities accept them more often than the "un-African" script assumes. For example, when he said that they wanted to show that a traditional African gay wedding was possible, he continued: "“We wanted people to know that a gay union can be accepted and celebrated by friends, family and the broader community" and "to show another side of the "hostility and violence against gay people.... We want to show that gay people are also accepted, respected and loved in their rural communities"” (de Waal 2013). Similarly, in his blog post responding to the hype, he wrote, "we wanted...to show that it is possible to have a traditional gay wedding ceremony and still receive support from our respective families" (Modisane 2013). According to Daily Maverick, KwaDukuza community members "turned up in droves to celebrate the couple's union" (de Waal 2013). The couple suspected that most came out of curiosity. "I'm sure they wanted to see who is wife of us both!" Thoba said (Agence France Press 2014), suggesting "that initially the community expected...to see two men draped in wedding dresses" (de Waal 2013). "But when the people from KwaDukuza arrived at our wedding they witnessed two very ordinary men in love, and they celebrated with us.'”

A key feature of the story they told was an almost total lack of family conflict. "“It's very rare for a black family to understand the homosexuality of their son, very, very rare,"' Cameron said. "'As a child I was scared at first, of disappointing them, but in fact they supported me, 
which makes me very happy"” (Agence France Press 2014). Thoba spoke about his own family in more detail. "I called a meeting at my house," he said. "The elders came and the first thing they asked me was if I had a pregnant girl.... I finally said that I felt feelings for other boys and they exclaimed that they had suspected it forever!'" His sister "announc[ed] that she was going to fast and pray for him to change," while his grandmother "“asked me to explain what two boys do in a bedroom...I could not answer that. So I made her understand that all she had felt for my grandfather, well it was the same for me."' Apart from that, other family were supportive. His mother was interviewed by eNCA at the wedding, saying, "I'm so happy. I have no worries. And I'm so grateful for the gifts from the Modisanes [Cameron's family]. I wish them well for the future and where they'll be living together"' (eNCA 2013b).

The couple directed their message of African community acceptance not only at the broader public, but also specifically to other black LGBTI people. "“[We] hope to inspire people out there who are still struggling to come to terms with their sexuality," Cameron said. "“We see no reason to hide in darkness as if there is something to be ashamed about.... If people are inspired by our love and actions and want to do the same to follow in our footsteps then we don't mind being labelled as "role models" in the LGBTI community" (Igual 2013). Their message landed with at least one black gay man from Thoba's hometown, Delana Majola (2013), who wrote an op-ed in the KwaZulu-Natal newspaper The Mercury headlined "Gay union made me feel like I belonged." Majola called it "a silence-breaking wedding" and said that "[a]s a gay man, I was happy that such a step (the wedding) was being taken by my fellow homosexuals, as I hoped to catch a glimpse of wedding fever that maybe someday could be mine." Sape and Vaivi Maodi-Swartz, whose story I discuss below, explicitly suggested that gay and lesbian couples tend to avoid participating in African wedding processes (News24.com 2015), and a similar idea 
ran through Thoba and Cameron's comments. "'We too have a right to participate in traditional ceremonies,"' Cameron insisted (de Waal 2013).

So the wedding, if not the marriage, was a deliberate political strategy meant to perform the claims that homosexuality is African, and that Africans are not intrinsically homophobic. Although the couple_-Thoba in particular — did reference the "prejudice" and "confusion" they encountered from some family members, Cameron specifically imputed this to the distortions of colonial rule, while insisting on an unbroken historical chain of gay presence in black communities. The couple's primary narrative about their African wedding was that it made visible their existing embeddedness within African communities, not that it introduced a foreign practice into those communities.

\section{Not the First}

The media did not erase that narrative- everything I quote above came from their stories, after all — but they did flatten it into a new version of the "un-African" script in which this gay African wedding was the "first." But it was not the first, at least not in the way virtually everyone presumed. The local paper got it closest: Although it was not quite a "legal gay wedding" in the way the paper meant, it almost certainly was the first gay wedding in KwaDukuza for a legally recognized couple, and probably the first gay wedding there of any legal status at all. It was possibly even the first same-sex wedding in town, gay or not, although that starts to become less certain. Loosen the qualifications any further than that and the KwaDukuza wedding's chances of a "first" virtually disappear.

This is because the southern African region has a richer history than most of same-sex marriages. Until recently, most of this history has had nothing to do with lesbian and gay identity 
and everything to do with prevailing understandings of African kinship. For example, in some communities a wealthy or high-status woman can, because of her stature, become a husband by marrying one or more wives (e.g., Gluckman 1950; Krige 1974; Wieringa 2005). Other forms of woman-woman marriage triggered by a range of circumstances unfold today among Sepedispeaking people in the country's north (Maphalle 2019). ${ }^{6}$ Another historical example of same-sex marriage that involves actual same-sex sex occurred between older and younger male mineworkers (Achmat 1993; Moodie 1988; Niehaus 2002). The younger partner in these temporary marriages played the wife's role in sexual and domestic activities in return for food, money, and gifts. Same-sex marriage also occurs with some frequency among sangomas, or traditional healers (N. Z. Nkabinde 2008; N. Nkabinde and Morgan 2005; Reid 2013). When the sangoma is called to the profession by an ancestor of a different sex, they may marry an assistant of the same sex as themselves. This need not be connected to LGBTIQ identity, but today it often is (N. Z. Nkabinde 2008; Reid 2013).

These and other examples, across their deep differences, all speak to an enduring legibility of same-sex marriages under certain circumstances (provided they were heterogender, a point I discuss more below). Meanwhile, other African weddings more connected to lesbian and gay identity have also occurred. Ron Louw (2001) documented a practice of informal marriages among men in the KwaZulu-Natal community of Mkhumbane in the 1950s. At least one informant retrospectively described some of the men in those marriages as "gay," although it is hard to know whether the men used that term at the time, or what it might have meant to them. Even more directly relevant to Thoba and Cameron's wedding, numerous black lesbian and gay couples have celebrated weddings that included African elements, both before and after the Civil Union Act (see, e.g., DeBarros 2017; Haffajee 1997; Judge, Manion, and De Waal 2008) None of 
the coverage of Thoba and Cameron's wedding indicated any awareness of this history, although to be fair Cameron himself suggested that "'this was the first gay wedding that we know of in KwaZulu-Natal and, we think, the first traditional gay ceremony in the country"' (de Waal 2013).

\section{The Location of Cultural Authority}

The mistaken belief this was unprecedented was the only point on which the couple agreed with the elder male traditionalists the media interviewed to speak on behalf of African culture. Many of the media stories were framed as a kind of debate, with the couple on one side intercut with an "African culture expert," in each case an older Zulu man, on the other. Much like British colonizers when they established colonial systems of customary law (Mnisi 2007), the media assumed that senior patriarchs held exclusive knowledge and authority to speak about the substance of African traditions.

The traditionalist who appeared most often in the coverage was Dr. Velaphi Mkhize of the Umsamo Institute, a school and consultation organization he founded "to bring back that culture, the culture of people, the culture of an African, ubuntu" (Umsamo Institute n.d.). ${ }^{7}$ In the initial clip from eNCA (2013a), he said that "we have never heard of such a thing in our culture, our tradition" and that he did not think the ancestors "will accept such a thing." An interview with the Durban-area Daily News paraphrased him as saying that "marriage was traditionally a way to expand the family. Wives were expected to give birth to children who would carry their families' names forward. Homosexuality made this impossible" (Kweyama 2013).

Both of these statements reference the idea that, as conventionally understood, African marriage is a union not of two individuals but of two extended family lines. Deceased ancestors are understood to still exist and act in the world, bringing good fortune or bad upon their living 
descendants depending on how they view those descendants' management of the family line. The customary processes for forming African marriages include overtures to the ancestors to introduce the new wife. Ancestors are typically understood to desire the continuation of their line through biological offspring more than anything else, and this is where the perceived problem with same-sex relations resides.

Another set of objections questioned procedural details of the ceremony, such as around the slaughtering of one bull rather than the conventional two, or around the inclusion of vows and a kiss. A particularly full expression of these objections appeared as a comment on the blog post Cameron wrote after the wedding. Under the handle TakaPhila NoVuna, the commenter wrote, "to me this seems like a white wedding between 2people dressed up in traditional attire... Not to be $\mathrm{p}[\mathrm{e}] \mathrm{tty}$ but do we have, 'you may kiss the bride/bridegroom' in our traditional weddings? Just asking” (Modisane 2013). The commenter had a point. Indeed, a sealing kiss is not part of the conventional Zulu wedding ceremony, nor is the presence of an officiant. The ceremony typically called a Zulu "wedding" today is a "delivery" of the bride by her people to the groom's household, and most of this ceremony's elements emphasize the families' relationship to each other. When a pastor stands before the couple as they face each other, promise themselves to each other, and seal their promise with a kiss, this constitutes a much more couple-focused ceremony and is certainly influenced by white wedding practices.

Even still, there is little doubt that Thoba and Cameron had their families' and communities' support. Thoba's mother and several neighbors (all women) expressed their happiness in interviews. Yet even as these women spoke about the wedding as a meaningful practice within their undeniably African community, the media did not frame any of them as speaking on behalf of "African culture." They were curious neighbors and loving mothers, not 
cultural authorities. Such authority remained the property of elder men who did not even come from Cameron's or Thoba's communities, men whose visions of the African past were scrubbed clean of homosexuality and same-sex marriages. ${ }^{8}$ By authorizing these men to speak on behalf of African tradition, the media's new twist on the "un-African" script continued to deny Thoba and Cameron their claim on African histories. But even more importantly, it located "African culture" in the rules applied by elder men rather than in the daily practices of all African community members, men and women, straight and gay. By excising Cameron and Thoba from African histories, the media also obscured their embeddedness in contemporary African communities. This excision is even more central to the story of Sape Maodi and Vaivi Swartz, and I turn to that story now.

\section{It's a Family Affair: The Social Embeddedness of Sape Maodi \& Vaivi Swartz's Lobola}

With the tricks of the tabloid trade, the exclamation point told the story. "Black lesbian couple pays lobola!" shouted the Daily Sun in December 2015.

The customary practice through which recognized marriages are formed in most black South African communities, lobola centers on a large gift of "cattle," today often at least partly in the form of cash, from the groom to the bride's family. Lobola is a highly, even intrinsically gendered process. How, the exclamation pointedly asked, could a lesbian couple possibly perform it?

And so the lobola of Vaivi Swartz and Sape Maodi became the center of their public story. As with Thoba and Cameron's wedding, Vaivi and Sape's lobola was portrayed as something "new," as bridging the historic "gap" between un-African homosexuality and African 
homophobia. And as with Cameron and Thoba, this overstatement of newness detached Sape and Vaivi from their place in the flow of African histories.

But even more telling in Sape and Vaivi's case was how the framing of the coverage downplayed their present embeddedness in current African communities, and lobola was central to this, as well. For reporters telling the story, lobola was a barrier, a "challenge for [the couple] and their families" (Wesi 2015). Lobola's sharply gendered roles seemingly embodied the essential heterosexuality of African culture, marking the precise location of what the Daily Sun reporter called the "gap between tradition and homosexual relationships" (News24.com 2015).

This idea was not absent from Vaivi's and Sape's own accounts, but it was not the primary way they told their story. Speaking in part to gay and lesbian couples who avoided lobola, Sape and Vaivi portrayed lobola as a path they took in order to secure recognition for their marriage from their families and communities. They told a story not of hostile rejection by a general African public, but instead of a somewhat confused mis-recognition by two specific, largely accepting African families. As Vaivi and Sape told it, the couple and both their families were all willing participants in the lobola negotiations. By talking about lobola, they surfaced important differences in the ways everyone understood the new marriage, and worked through those differences to reach a mutual understanding.

In other words, Sape and Vaivi told a story in which lobola embodied their embeddedness in African communities, not their separation from them. As African women, they had rightful claims to the lobola process and to the powerful social meanings it carries, not just for the married couple but for the kinship constellation the marriage constitutes around them. They used lobola to work through and on their relations with their families, making possible the marriage 
they envisioned in the contexts where they lived their lives. For Sape and Vaivi, lobola was not the problem — or, at least, not only the problem. It was also the solution.

It began for them with a choice. "“The initiation point for us was saying we want to do this process,"” Sape told the Daily Sun (News24.com 2015). "If we don't do it that way," she said, "most people would not respect our marriage when it comes to African customs and tradition. It wouldn't gain the same respect that a heterosexual marriage carries with it." As Vaivi put it, in a reporter's paraphrase, "the driving force... was to ensure their families blessed and accepted their union. It ensured the ancestors of both families knew about and accepted the new members."

Sape and Vaivi's telling of the tale thus begins with them seeking out lobola, much like any different-sex couple hoping to secure family and community recognition for their marriage. This is not to say that they saw what they were doing as routine. They contrasted their choice with other "gay couples," who "usually...simply sign the marriage contract and not pay the lobola" (News24.com 2015). They wanted to provide a way for other gay couples to have, as Sape put it, a "choice on whether they are willing to challenge traditional norms"” (DeBarros 2016). "'We had never seen or heard of lesbian lobola,"” Sape said, but "“all [we] wanted was that we will be officially recognised traditionally as a married couple"' (Sithole 2018).

They thus approached lobola hoping to change a practice that is " not inclusive of homosexuals" (News24.com 2015, quoting an unnamed partner), and in this sense they did tell a narrative of changing African traditions to accommodate lesbian and gay relationships. But they framed this change as part of African culture's ongoing evolution, not as a breakthrough moment 
of bridging the "gap" between homosexuality and African culture. "We know our tradition,"” Sape insisted (Wesi 2015).

Just because we're lesbian doesn't mean we have to move away from those traditions. [Rather] let's integrate our lives into the culture...Culture is not written in stone; culture is historical, and if history does not progress with the next generation, we'll be left behind. We want to teach our kids the same things that we were taught.

By engaging lobola, in other words, they hoped to preserve their existing claim to African traditions. They "kn[e]w [their] tradition" and saw no reason that they should have to "move away from" it. Better to adapt it so that "we" (the couple? lesbian and gay Africans? all Africans?) will not "be left behind." The African "culture" Sape spoke of here was not a rigid monolith on the other side of a "gap," but instead a negotiable and contingent field of practices lived out by the African communities where Sape and Vaivi themselves had built their lives. The couple knew their own negotiations would take some work, but, as Sape told it, that kind of work was what culture was all about.

\section{Well-Meaning, but Wrong Meaning: Their Families}

Their key partners in this work were their families, and the couple portrayed them as enthusiastic participants, further confounding the "bridging the gap" script. The Swartz family, in particular, had clear expectations for how this would go. Vaivi "had already been out [as a lesbian] since 1997 when she was in Grade 7, and her parents were readily accepting" (Wesi 2015). They “consider[ed] their daughter 'the man', so they felt she would give the lobola." The 
Maodi family, for their part, had "hardly expected Sape...to announce she is lesbian in 2009," but had come to terms with it. They still expected to receive lobola when she married, however.

Far from rejecting the couple's lobola, both families brought ready expectations into the process. The question was never whether the lobola would happen. The question was how. The core problem was that the families' expectations for the lobola process, and the marriage, did not match the couple's own. The Swartz and Maodi families both saw their daughters' marriage as a highly gendered union of, more or less, husband and wife, and it thus seemed natural that Vaivi would pay the lobola to the Maodis. As for Vaivi, she "describe[d] herself as 'deeply traditional', so she was willing to fork out lobola money” (Wesi 2015). But Sape felt uneasy. “'I felt it was unfair because it is a 50/50 relationship," she said, “'and I wasn't comfortable with the fact that my family had to be the recipients." She thought that "a few lunches between families should be enough to unite them, and the lobola could instead be used to start a life together."

Note how the couple described themselves here as struggling not with some abstract "African culture," but with their own specific African families. One key effect of the "unAfrican" script and other monolithic representations of African culture is to obscure how "culture" and "tradition" are lived within specific families and communities, among specific people with specific personalities and histories who stand in specific relationships to each other. Even deceased ancestors are engaged — or insert themselves — as particular people who stand in a particular position vis-à-vis, say, a marrying granddaughter and the kin who have sanctioned her marriage (see, e.g., N. Z. Nkabinde 2008). As African cultural practices circulate in these highly specific relational contexts, it is common for them to produce ambiguity and conflict around what culture "requires" in a given circumstance (Comaroff 1980; Comaroff and Roberts 1981). 
By obscuring the social embeddedness of those practices labeled as "cultural," the "bridging the gap" script erases the contested nature of "African culture."

In the specific context of Sape and Vaivi's negotiations, the patriarchal character of African marriage mattered not by producing automatic rejection, but instead by providing a framework onto which the families hung their understandings of their respective daughters' gendered selves. They perceived a kind of heterogender loophole in the heterosexual mandate of African marriage and assumed that their daughters were walking through it. Vaivi was prepared to take that path, playing out what she saw as her own "“deeply traditional"” role. But Sape resisted, insisting on the "50/50" nature of the couple's relationship. She sought a way to retain lobola's function of building a relationship between the two families, but without imposing heterogender roles onto her egalitarian marriage.

\section{Minding the "Gap": The Media}

While the media included this information, they tended to downplay or obscure it. For example, in the Daily Sun story, each quote from the couple (primarily from Sape) was preceded by a paragraph framing the couple's words within the "bridging the gap" script. Before Sape said that the couple themselves sought to perform lobola, the reporter framed this as a reach across the gap by saying that they have "shown it is possible to stay true to oneself and still respect African tradition" (News24.com 2015). Before she said that they "“did the entire process like a heterosexual couple would do,", the reporter preemptively contrasted that with "African culture," in which "the man pays lobola to the wife's family, to thank them for raising her and to allow him to take her from them." The structure of the article repeatedly led with the supposed historic difference separating homosexuality and "African culture," placing the couple's 
subsequent words inside this frame of historic difference and thereby positioning the women as, in the article's own words, "bridg[ing] the gap between tradition and homosexual relationships."

This article's structure demonstrates how the historical erasures emphasized in Cameron and Thoba's story support the contemporary distortions seen in Sape and Vaivi's. By erasing queer histories, the "bridging the gap" script frames contemporary queer Africans' interactions with family and community as unprecedented, flattening even cooperative negotiations into binary conflicts. In Vaivi and Sape's case, reporters awkwardly pressed the families' wellmeaning but misguided heterogender assumptions into a script that calls for a more direct conflict rooted in homophobic rejection. This contemporary distortion was supported by an erasure of the region's small but significant history of different forms of same-sex marriage, discussed above, that all somehow placed the two spouses into distinct, heterogender marital roles. Across many differences, each of these different marital forms has involved one spouse stepping into a cross-gender kinship role due to specific local, familial, or personal circumstances. A prominent woman takes a wife and becomes patriarch of her own homestead and a link in the patrilineage. A young man working on the mines becomes a temporary wife and performs domestic care work. In some cases, especially among sangomas, this gender-crossing might extend to identity or self-presentation. But what has been consistent is that the kinship roles of husband/father and wife/mother remain in place even as both are filled by people of the same sex.

None of these same-sex marital forms was ever more than a circumstantial exception, and only some have been securely institutionalized in their respective social contexts. Nonetheless, their recurrence suggests a submerged capacity within southern African kinship systems that Sape's and Vaivi's families drew on as they made sense of this marriage. The Swartzes simply 
assumed that their daughter, Vaivi, was "the man" (Wesi 2015), and the Maodis readily agreed. They had little trouble understanding their daughters' lesbian relationship provided their marital roles remained heterogender.

\section{Lesbian and Gay Identity, Gender, and Marriage}

And indeed they were far from the first to view a lesbian relationship through a heterogender lens. To the contrary, over the past two decades many researchers have documented that relationships among urban black South African lesbians have very often followed a "butchfemme" or "butch-straight woman" model clearly influenced by a heterogender logic (Matebeni 2011; Smuts 2011; Swarr 2012). Similar patterns have existed among gay men, for example in small towns where feminine gay "ladies" have been the girlfriends of masculine straight "gents" (Reid, 2013). This heterogender logic has been so strong that it has undergirded the boundaries of sexual identity itself, as masculine men and feminine women in these relationships typically have been understood as straight, and only the gender-transgressive partners as gay or lesbian.

But as apartheid formally ended, a newer model of gay identity and relationships began to grow. The constitution's protection of sexual orientation opened crucial space for organized activism on these issues, most of which has been framed around LGBTI identities as they are understood by the transnational human rights organizations that primarily fund this work (Reid 2013). Distinguishing the LGB from the $T$ and the $I$, these human rights understandings define lesbian or gay identity around the sexed or gendered direction of a person's sexual and romantic desires, rather than the gendered nature of their self-expression or role in a given relationship. Indeed the idea of relationship "roles" itself disappears, as these understandings emphasize similarity and equality in lesbian and gay relationships, rather than difference. This sexual 
orientation model of lesbian and gay identity (Yarbrough 2018a) has grown more influential in black communities since apartheid's formal end, triggering ripples that have reshaped the boundaries and meaning of the full range of LGBTIQ identities (Livermon 2015). As queer visibility has grown, the tension between these different understandings has also grown (Fiereck 2018; Matebeni 2009). This remains a time of transition and struggle not merely over the acceptance of LGBTIQ identities, but over their very meanings.

From this vantage point, both the couple and their families were embedded in a broader historical transition around the definition of lesbian and gay identities and relationships in black South African communities, a transition that is itself influenced by an even longer history of same-sex relating and marrying in the region. By attending to this history, we apprehend the fullest meaning of the families' heterogender assumptions. Far from rejecting something new or confusing brought to them from the outside, the families instead engaged their lesbian daughters via an underappreciated cultural understanding that has long recurred in circumstances like these-if not, until now, exactly like these. Meanwhile their daughters, like many of their generation, insisted on their continued claim to cultural belonging while engaging their families through a different, more egalitarian understanding of lesbian identity and marital relationships. In their struggle around lobola, the Maodis and Swartzes reproduced this era's broader tensions around the meaning of LGBTIQ identities in black South Africa. The families' and daughters' entanglement with each other channeled their broader embeddedness in the forces shaping black South African sexualities today.

And indeed this can be said not just for LGBTIQ identities specifically, but for gender more broadly. After all, struggles abound over gendered power in different-sex relationships, as well. In my own research on marriage in Maqongqo, KwaZulu-Natal, many heterosexual 
women, like Sape, spoke to me of their desires for a "50/50" marriage, and of their struggles with both their male partners and their families of origin in pursuit of these desires (Yarbrough 2018). Indeed, this "50/50" trope circulates widely in contemporary South Africa (see, e.g., Hassim 2003; Hunter 2010; Ndinda et al. 2007), and although it does not mean exactly the same thing in every context, it has nonetheless carried critiques of myriad patriarchal arrangements, including those specifically understood as African. Between constitutional guarantees of gender equality that have emboldened women in their own daily lives (Mnisi Weeks 2017), and economic deprivation that has undermined men's pursuit of breadwinner masculinities (Morrell 2001), the era since apartheid's formal end has been one of heightened gender and sexual struggle (Hassim 2009; Posel 2004). Romantic and marital relationships have been ground zero for that struggle, and Sape and Vaivi's story is embedded in that context, as well. The "bridging the gap" script obscures this, pushing us to see theirs as an exceptional story of transcending African homophobia rather than a typical story of contemporary gender struggle in African communities.

\section{Conclusion}

Perhaps nothing better demonstrates how Vaivi, Sape, and their families were embedded in this broader gender struggle than the way they resolved their disagreement. Because the Swartz family had expected Vaivi to pay lobola, and the Maodi family had expected to receive it, the couple agreed that lobola would be paid to the Maodis. But they insisted on one key variation: The couple, not just Vaivi alone, would pay the lobola together. "It's not her money or my money," Sape said (Wesi 2015). "It is a 50/50 relationship."

Among the notable things about this arrangement is that it was less notable than it may

have seemed. As lobola has become more difficult to complete, some different-sex couples have 
also begun paying their lobola together, the woman secretly helping the man so they can complete their marriage in the face of her family's demands. Systematic research on this phenomenon is sorely needed, both to document its scale and to examine how the couples who use this strategy understand it. Nonetheless, chatter about it is common.

It is surely no accident that Sape and Vaivi and their families landed on such a similar solution. After all, the tensions surrounding lobola — cultural, ideological, economic, generational, gendered - affect black South African communities in general, not just LGBTIQ people specifically. The core tension in Sape and Vaivi's negotiations-how to balance the two partners' desires for their individual relationship with the two families' expectations for their own collective reproduction — is nearly universal in black romantic relationships today, as it has been for decades or more (Yarbrough 2018). In this current era, it seems that one response to these tensions has been for couples to separate the paying of lobola from the receiving of it, using their dominion over the action of paying to assert their own agency over their marriage. The key difference, of course, is that that Vaivi and Sape did this openly, while virtually all different-sex couples who use this strategy do so secretly. Sape and Vaivi's openness was almost forced by the atypical nature of their lobola, and it marks the distinctive place that LGBTIQ people do occupy in relation to these broader tensions. At the same time, in Sape and Vaivi's case this distinction carried an ironic benefit, allowing the couple to openly discuss their unease with a set of tensions that different-sex couples must manage in private.

These tensions are very difficult, helping explain why the dominant story of South African relational life today, especially among younger black South Africans, is of flexible and ambiguously defined relationships. In this respect it is Cameron and Thoba's marriage that is more typical, for it ended in divorce two years after it began. Appearing frequently in the news as 
a kind of celebrity gossip item in the years after their wedding, Thoba and Cameron were surrounded by rumors of infidelity and abuse until Cameron filed for divorce in July 2015. While the rumors were never confirmed by the now ex-spouses, they focused on the same concerns that dog different-sex relationships in this era of pitched gender turmoil.

The "bridging the gap" script obscures these broad similarities by portraying black LGBTIQ South Africans as having landed somehow into African communities, not as having grown up within them. Adapting the "un-African" script for a new era of heightened black LGBTIQ visibility and inclusion, the "bridging the gap" script continues to presume a historic gap between homosexuality and African culture, while adding a new chapter in which the gap is bridged. Positioning black LGBTIQ people as acceptable outsiders rather than authentic insiders, the "bridging the gap" script denies LGBTIQ people any claim to African histories while flattening their complex contemporary struggles into simplistic binary battles. Perhaps worst of all, the script misses how LGBTIQ experiences refract the broader gender struggles that are a hallmark of this era in black South African history.

What this means for the future is harder to say. As this essay was going to press, Sape Maodi participated in a talk radio show about same-sex lobola and about women's participation in lobola negotiations, hosted by gay public intellectual Eusebius McKaiser (2019). While a prominent traditional leader was on hand to represent that perspective, a woman sangoma was also present, and both were asked to speak about their understandings of "African culture." The conversation also made repeated and deliberate connections between same-sex marriages and broader questions of gender equality. Perhaps this is a small indicator that assumptions of "unAfrican homosexuality" and "African homophobia" might finally loosen their seeming stranglehold on public discourse. 
Meanwhile, the daily lives of black LGBTIQ South Africans remain embedded in actual African communities. The struggles that play out there are every bit as rounded and complex as those described here, producing a range of outcomes that far exceed any binary script. To be sure, the "un-African" script does patrol many of these communities, claiming authority over gendered behavior and legitimizing violent enforcement against those who dare to differ. But even still, black LGBTIQ South Africans and their families turn to custom, creating "usable traditions" that rework the meanings, practices, and obligations that the "un-African" script attempts to deny them (Livermon 2015). As these everyday South Africans engage these customs, simultaneously and inseparably black and queer, they deny the "un-African" and "bridging the gap" scripts' claims to truth. What remains to be seen is if they can also, ultimately, deny their claim to power.

\section{ENDNOTES}

${ }^{1}$ In this paper I discuss two couples, and I generally use their first names in order to avoid confusion when I am discussing their family members.

${ }^{2}$ Sexual and gender identity terminology is especially complex in post-colonial contexts such as South Africa. In this paper I use whatever term or variation of the LGBTIQ acronym best fits the particular context, while regarding all terms as provisional.

${ }^{3}$ Racial terminology is also especially fraught in South Africa. In particular, the term "black" has meant different things in different periods. Following common contemporary usage, in this paper I use the terms "black," "African," and "black African" to refer to the same broad set of people, choosing the term that best suits the context while acknowledging the slipperiness of the categories. Generally, I use "African” to refer to matters and identifications specifically relating 
to African customary practices or the African continent. Otherwise, I use "black."

${ }^{4}$ I also conducted a preliminary web search for isiZulu-language coverage of these two couples but did not locate any. A detailed study of African-language media, and especially radio, discourse in South Africa about these issues would be very helpful and would likely differ in important ways from the dynamics I trace here.

${ }^{5}$ This means that the KwaDukuza wedding had no state law significance. It could be seen as an attempt to secure recognition under customary law, but there is no indication they sought to do that.

${ }^{6}$ For an incisive exploration of the multiple and ambiguous meanings of similar relationships in their own family in Kenya, see Musangi 2018.

${ }^{7}$ Ubuntu translates as something like "humanity" or "personhood" and refers to the importance of collective values in African communities.

${ }^{8}$ Mkhize may have obliquely acknowledged woman-woman marriages when he told eNCA (2013b), "We've never seen a man marrying another man," with no mention of women marrying women. He also said of Cameron and Thoba's wedding, "I don't know if it is a groom and a bride, or a groom and a groom," again perhaps implicitly acknowledging that different-gender, same-sex marriages have occurred.

\section{REFERENCES}

Achmat, Zackie. 1993. “'Apostles of Civilised Vice': 'Immoral Practices' and 'Unnatural Vice' in South African Prisons and Compounds, 1890-1920." Social Dynamics: A Journal of African Studies 19: 92-110. https://doi.org/10.1080/02533959308458553.

Agence France Press. 2014. "Le plus afro des couples gay fête un an de mariage.” Agence 
France Press, March 7, 2014. https://www.lexpress.fr/actualites/1/monde/le-plus-afrodes-couples-gay-fete-un-an-de-mariage_1498196.html.

Awondo, Patrick, Peter Geschiere, and Graeme Reid. 2012. "Homophobic Africa? Toward A More Nuanced View." African Studies Review 55: 145-68. https://doi.org/10.1017/S0002020600007241.

Coly, Ayo A. 2013. “ASR FORUM: HOMOPHOBIC AFRICA?: Introduction.” African Studies Review 56: 21-30.

Comaroff, John L. 1980. "Bridewealth and the Control of Ambiguity in a Tswana Chiefdom.” In The Meaning of Marriage Payments, edited by John L. Comaroff, 161-96. London: Academic Press.

Comaroff, John L., and Simon Roberts. 1981. Rules and Processes: The Cultural Logic of Dispute in an African Context. Chicago: University of Chicago Press.

Currier, Ashley. 2012. Out in Africa: LGBT Organizing in Namibia and South Africa. Minneapolis: University of Minnesota Press.

- 2019. Politicizing Sex in Contemporary Africa: Homophobia in Malawi. New York: Cambridge University Press.

DeBarros, Luiz. 2014. “AFRICAN GAY LOVE - A YEAR LATER.” MambaOnline. February 13, 2014. http://www.mambaonline.com/2014/02/13/african-gay-love-a-year-later/. —. 2016. "Lesbian \& Gay Marriage in South Africa: Part 1 - Love \& Lobola." MambaOnline. March 1, 2016. http://www.mambaonline.com/2016/03/01/lesbian-gaymarriage-south-africa-part-1-love-lobola/.

—. 2017. “It's Love! Meet Ekurhuleni’s Longest Married Gay Couple.” MambaOnline. December 7, 2017. http://www.mambaonline.com/2017/12/07/love-meet-ekurhulenis- 
longest-married-gay-couple/.

Dürr, Benjamin. 2013. "Die Hochzeit von Tshepo Und Thoba.” Spiegel Online, April 18, 2013. http://www.spiegel.de/panorama/erste-homo-hochzeit-nach-traditionellen-riten-in-afrikaa-894709.html.

eNCA. 2013a. Gay Couple to Marry in Traditional Zulu Wedding Ceremony. https://www.youtube.com/watch?v=V3YHxjsc5_M\&list=UUI3RT5PGmdi1KVp9FG_C neA\&index $=44$.

—. 2013b. Gay Wedding - Traditional African Gay Wedding a First. https://www.youtube.com/watch?v=1ZLB9Y71Pw8\&index=2\&list=LLvTXto1TDtAM_ M6vDgZYdUA\&t=10s.

Epprecht, Marc. 2004. Hungochani: The History of a Dissident Sexuality in Southern Africa. Montreal: McGill-Queen's University Press.

- 2008. Heterosexual Africa?: The History of an Idea from the Age of Exploration to the Age of AIDS. Athens, OH: Ohio University Press.

The Eusebius McKaiser Show. 2019. "Queering Lobola and Discussing the Role of Women in Lobola.” Hosted by Eusebius McKaiser. 702, July 17.

FAB Blog. 2013. "FAB Report: The First Legal Traditional Gay Wedding in Africa." Blog attached to FAB Magazine. April 9, 2013. http://fabmagazineonline.com/fab-report-thefirst-legal-traditional-gay-wedding-in-africa/.

Fiereck, Kirk. 2018. “Queer Customs, Customarily Queer.” Medicine Anthropology Today. February 1, 2018. http://www.medanthrotheory.org/read/10018/queer-customscustomarily-queer.

Gaynor, Gerren Keith. 2013. “Africa Has Its First Traditional Gay Wedding?” Black Enterprise 
(blog). April 11, 2013. http://www.blackenterprise.com/first-african-gay-wedding-held/. Gluckman, Max. 1950. "Kinship and Marriage among the Lozi of Northern Rhodesia and the Zulu of Natal.” In African Systems of Kinship and Marriage, edited by A. R RadcliffeBrown and Daryll Forde, 166-206. London: Oxford University Press for the International African Institute.

Haffajee, Ferial. 1997. "Gay Couple Tie the Knot.” The M\&G Online, September 5, 1997. https://mg.co.za/article/1997-09-05-gay-couple-tie-the-knot/.

Hassim, Shireen. 2003. “The Gender Pact and Democratic Consolidation: Institutionalizing Gender Equality in the South African State." Feminist Studies 29: 505-28.

—. 2009. "Democracy's Shadows: Sexual Rights and Gender Politics in the Rape Trial of Jacob Zuma.” African Studies 68: 57-77. https://doi.org/10.1080/00020180902827431.

Hoad, Neville. 2007. African Intimacies: Race, Homosexuality, and Globalization. Minneapolis: University of Minnesota Press.

Huffington Post. 2013. “Africa’s First Traditional Gay Wedding? Tshepo Cameron Modisane and Thoba Calvin Sithole Tie the Knot." Huffington Post, April 8, 2013, sec. Queer Voices. https://www.huffingtonpost.com/2013/04/08/africa-first-gaywedding_n_3037637.html.

Hunter, Mark. 2010. Love in the Time of AIDS: Inequality, Gender, and Rights in South Africa. Bloomington, IN: Indiana University Press.

Igual, Roberto. 2013. “A Gay African Love Story.” MambaOnline. February 14, 2013. http://www.mambaonline.com/2013/02/14/a-gay-african-love-story/.

Judge, Melanie. 2017. Blackwashing Homophobia: Violence and the Politics of Sexuality, Gender and Race. New York: Routledge. 
Judge, Melanie, Anthony Manion, and Shaun De Waal, eds. 2008. To Have and to Hold: The Making of Same-Sex Marriage in South Africa. Auckland Park, South Africa: Fanele.

Krige, E. J. 1974. "Woman-Marriage, with Special Reference to the Lovedu. Its Significance for the Definition of Marriage.” Africa, 11-37.

Kweyama, Hlengiwe. 2013. “"Nothing Evil about Our Gay Wedding”.'” Daily News, April 9, 2013. https://www.iol.co.za/dailynews/news/nothing-evil-about-our-gay-wedding1497615.

Lewis, Desiree. 2011. "Representing African Sexualities." In African Sexualities: A Reader, edited by Sylvia Tamale. Cape Town, Dakar, Nairobi, and Oxford: Pambazuka Press.

Livermon, Xavier. 2015. "Usable Traditions: Creating Sexual Autonomy in Postapartheid South Africa." Feminist Studies 41: 14-41.

Louw, Ronald. 2001. "Mkhumbane and New Traditions of (Un)African Same-Sex Weddings." In Changing Men in Southern Africa, edited by Robert Morrell. Pietermaritzburg: University of Natal Press.

MailOnline. 2013. “Africa’s First Traditional Gay Wedding: Men Make History as They Marry in Full Tribal Costume... and Say They Can’t Wait to Be Parents.” MailOnline, April 9, 2013. https://www.dailymail.co.uk/news/article-2306180/Africa-s-traditional-gaywedding-Men-make-history-marry-tribal-costume--say-t-wait-parents.html.

Majola, Delana. 2013. “Gay Union Made Me Feel like I Belonged.” The Mercury, April 12, 2013.

Maphalle, Kagiso. 2019. “Children’s Rights in Woman-to-Woman Marriages: A Study of Pedi Ngwetsi Ya Lapa Customary Marriage.” Presented at Gender, (Inter)Generation, and Negotiating Power in Families Workshop, University of Cape Town, January 22. 
Matebeni, Zethu. 2009. "Feminizing Lesbians, Degendering Transgender Men: A Model for Building Lesbian Feminist Thinkers and Leaders in Africa?.” Souls 11: 347-354.

—. 2011. "Exploring Black Lesbian Sexualities and Identities in Johannesburg." PhD diss., University of the Witwatersrand.

—. 2014. "How NOT to Write about Queer South Africa." In Reclaiming Afrikan. Queer Perspectives on Sexual and Gender Indentities, edited by Zethu Matebeni, 61-64. Athlone, South Africa: Modjaji Books.

Matebeni, Zethu, and Thabo Msibi. 2015. "Vocabularies of the Non-Normative." Agenda 29: 39. https://doi.org/10.1080/10130950.2015.1025500.

Mnisi, Sindiso. 2007. “(Post) Colonial Culture and the South African Legal System: Understanding the Relationship between Living Customary Law and State Law." Zeitschrift Für Rechtssoziologie 28: 241-251.

Mnisi Weeks, Sindiso. 2017. Access to Justice and Human Security: Cultural Contradictions in Rural South Africa. New York, NY: Routledge.

Modisane, Cameron. 2013. "Our Traditional African Gay Wedding in KZN.” MyNews24 (blog). April 9, 2013. https://www.news24.com/MyNews24/Our-Traditional-African-GayWedding-in-KZN-20130409.

Moodie, T. Dunbar. 1988. "Migrancy and Male Sexuality on the South African Gold Mines." Journal of Southern African Studies 14: 228-56.

Morrell, Robert, ed. 2001. Changing Men in Southern Africa. Pietermaritzburg: University of Natal Press.

Msibi, Thabo. 2011. "The Lies We Have Been Told: On (Homo) Sexuality in Africa.” Africa Today 58: 55-77. https://doi.org/10.2979/africatoday.58.1.55. 
Musangi, Neo Sinoxolo. 2018. "Homing with My Mother / How Women in My Family Married Women.” Meridians 17: 401-14. https://doi.org/10.1215/15366936-7176549.

Naijalog. 2013. "Video: First Official Traditional African Gay Marriage between Tshepo Cameron Modisane and Thoba Calvin Sithole.” Naijalog (blog). April 9, 2013. https://naijalog.com/video-first-official-traditional-african-gay-marriage-between-tshepocameron-modisane-and-thoba-calvin-sithole/.

Ndinda, Catherine, Ufo Okeke Uzodike, Chiweni Chimbwete, Robert Pool, and Mdp. 2007. "Gender Relations in the Context of HIV/AIDS in Rural South Africa." AIDS Care 19: 844-49. https://doi.org/10.1080/09540120701203923.

News24.com. 2015. “Black Lesbian Couple Pays Lobola!” DailySun. December 26, 2015. https://www.dailysun.co.za/News/National/black-lesbian-couple-pays-lobola-201512262.

NewsOne Staff. 2013. "Two Men Tie the Knot In Africa's 'First Traditional Gay Wedding."” News One (blog). April 9, 2013. https://newsone.com/2366847/south-african-gayweddings-tshepo-cameron-modisane-thoba-calvin-sithole/.

Niehaus, Isak. 2002. "Renegotiating Masculinity in the South African Lowveld: Narratives of Male-Male Sex in Labour Compounds and in Prisons.” African Studies 61: 77-97. https://doi.org/10.1080/00020180220140082.

Nkabinde, Nkunzi, and Ruth Morgan. 2005. “"This Has Happened Since Ancient Times...It's Something You Are Born With': Ancestral Wives Amongst Same-Sex Sangomas in South Africa." In Tommy Boys, Lesbian Men and Ancestral Wives: Female Same-Sex Practices in Africa, edited by Ruth Zilla Morgan and Saskia Wieringa, 231-60. Johannesburg: Jacana Media. 
Nkabinde, Nkunzi Zandile. 2008. Black Bull, Ancestors and Me: My Life as a Lesbian Sangoma. Auckland Park, South Africa: Fanele.

Nofemele, Lumka. 2013a. "Pair Tie Bold Knot.” Sunday Tribune, April 7, 2013. https://www.iol.co.za/news/south-africa/kwazulu-natal/pair-tie-bold-knot-1496499.

—. 2013b. "YES I DO! The Stylish Gay Zulu Wedding." Sunday Independent, April 7, 2013. https://www.iol.co.za/news/south-africa/kwazulu-natal/pair-tie-bold-knot-1496499.

Nyanzi, Stella. 2013a. "Dismantling Reified African Culture through Localised Homosexualities in Uganda." Culture, Health \& Sexuality 15: 952-67. https://doi.org/10.1080/13691058.2013.798684.

_. 2013b. "Rhetorical Analysis of President Jammeh's Threats to Behead Homosexuals in the Gambia." In Sexual Diversity in Africa: Politics, Theory, and Citizenship, edited by S. N. Nyeck and Marc Epprecht, 67-87. Montreal: McGill-Queen’s University Press.

Nyeck, S. N. 2013. "Mobilizing against the Invisible: Erotic Nationalism, Mass Media, and the 'Paranoid Style' in Cameroon.” In Sexual Diversity in Africa: Politics, Theory, and Citizenship, edited by S. N. Nyeck and Marc Epprecht, 151-69. Montreal: McGillQueen’s University Press.

Patil, Vrushali. 2018. “The Heterosexual Matrix as Imperial Effect.” Sociological Theory 36: 126.

Pinfold, Corinne. 2013. "South Africa: Gay Couple Hope Their Traditional Wedding Will Inspire the Black Community.” Pink News. April 8, 2013. https://www.pinknews.co.uk/2013/04/08/south-africa-gay-couple-hope-their-traditionalwedding-will-inspire-the-black-community/.

Posel, Deborah. 2004. "Getting the Nation Talking about Sex: Reflection on the Discursive 
Constitution of Sexuality since 1994." Agenda 62: 53-63.

Ratele, Kopano. 2014. “Hegemonic African Masculinities and Men’s Heterosexual Lives: Some Uses for Homophobia." African Studies Review 57: 115-30. https://doi.org/10.1017/asr.2014.50.

Reid, Graeme. 2013. How to Be a Real Gay: Gay Identities in Small-Town South Africa. Scottsville, South Africa: University of KwaZulu-Natal Press.

Sithole, Ayanda. 2018. “\#BONAWeddings: A Love That Conquered All.” Bona Magazine (blog). June 15, 2018. http://www.bona.co.za/bonaweddings-love-conquered/.

Sul 21. 2013. "Dois homens realizam o primeiro casamento gay em cerimônia tradicional africana.” Brazilian news website. Sul 21 (blog). April 8, 2013. https://www.sul21.com.br/postsrascunho/2013/04/dois-homens-realizam-o-primeirocasamento-gay-em-cerimonia-tradicional-africana/.

Swarr, Amanda Lock. 2012. "Paradoxes of Butchness: Lesbian Masculinities and Sexual Violence in Contemporary South Africa." Signs: Journal of Women in Culture and Society 37: 961-86. https://doi.org/10.1086/664476.

Tallie, T. J. 2013. "Queering Natal: Settler Logics and the Disruptive Challenge of Zulu Polygamy." GLQ: A Journal of Lesbian and Gay Studies 19: 167-89.

Tamale, Sylvia. 2011. "Researching and Theorizing Sexualities in Africa." In African Sexualities: A Reader, edited by Sylvia Tamale, 11-36. Cape Town, Dakar, Nairobi, and Oxford: Pambazuka Press.

— 2013. "Confronting the Politics of Nonconforming Sexualities in Africa." African Studies Review 56: 31-45.

Towle, Andy. 2013. "Two Men Marry in First Traditional African Gay Wedding: VIDEO." 
Towleroad (blog). April 7, 2013. http://www.towleroad.com/2013/04/africanwedding/. Umsamo Institute. n.d. "Vision." Umsamo Institute. n.d. http://umsamo.org.za/wpp/vision/. Waal, Mandy de. 2013. “My Big Fat Gay Zulu Wedding.” Daily Maverick. April 9, 2013. https://www.dailymaverick.co.za/article/2013-04-09-my-big-fat-gay-zulu-wedding/.

Wesi, Tsholofelo. 2015. "Lobola from a Gay Perspective.” The Citizen. November 26, 2015. http://citizen.co.za/news/south-africa/883829/lobola-from-a-gay-perspective/.

Wieringa, Saskia. 2005. "Women Marriages and Other Same-Sex Practices: Historical Reflections on African Women's Same-Sex Relations.” In Tommy Boys, Lesbian Men and Ancestral Wives: Female Same-Sex Practices in Africa, edited by Ruth Zilla Morgan and Saskia Wieringa. Johannesburg: Jacana Media. 